\title{
COMPUTER MEDIATED COMMUNICATION IN A CONTEXT OF MODERN ORGANIZATION: A SCOPING REVIEW
}

\begin{abstract}
Purpose - The present article aims to reveal and summarize key points of the application of information and communication technology (ICT) and Internet technology in the context of modern organization communication, related management processes.

Design/methodology/approach - methods of meta-analysis, comparative analysis and systemizing-syntesis are used in this article. A scoping review methodology was chosen as dominant for the research with the purpose of assessing key points in the context of Computer Mediated Communication (CMC) usage in modern organizations. The researh is based on a qualitative paradigm.

Findings - Results of the scoping review suggest that ICT and CMC are compatible and can be successfully applicable to solve the main challenges in management and control contexts of interorganizational, organizational, group (team) and inter-personal communication and related processes. In addition, this new combination of management methods and technological innovations has a great impact on opinion and behavior of customers and overall society, process improvement in business organizations, and change management.

Research limitations/implications - Firstly, a limited scope of organizations especially in Public and Non-governmental sector use CMC in everyday duties. Nevertheless, a usage of ICT and CMC requires not only the understanding of the theoretical background but also strict practical implication guidelines as well as measurement and evaluation indicators, targets, and an overall model for analyzing. Since this article is based on the scoping review where main findings and conclusions are outlined from a meta-analysis, case studies and comparative analysis towards a practical implication are not sufficiently elaborated. The second limitation which can also be called a future implication might be a wide scope and content of the CMC concept as well as the dynamics of the communication process in organizations, increasing demand from business organizations.

Practical implications -The research may serve as a starting point to a further scientific discussion regarding the usage ICT and CMC both separately and as a part of other hybrid project and process methods, optimization and continuous improvement of communication, learning, control and other related processes and systems in organization management.

Originality/Value - The main value of the presented article can be described as underlying spheres where CMC has the major impact in management of modern organizations: it takes effect in a wide field of internal and external processes as well as in overall process optimization activities and change management.

Keywords: Computer Mediated Communication (CMC); organization management; information and communication technology (ICT); Human Resource Management (HRM); leadership; technostress; online learning.

Research type: literature review.

JEL classification:

M15- IT Management,

D83 - Information and Knowledge, Communication.
\end{abstract}

\footnotetext{
${ }^{1}$ Laboratory of Business Innovation, Mykolas Romeris University, Lithuani, gedas.baranauskas@yahoo.com
} 


\section{Introduction}

In contemporary organizations and business processes, communication without Information and Communication Technologies (ICT) is unimaginable. Researchers, investigating the problems of organizational communication, concentrate on the effectiveness of Computer-Mediated Communication and Digital Communication which have become very significant in network-internet powered society. ICT is the exchange of the information, forming new practices of communication and decision making. Social media also engages in social networking when communicating with individual professional or general interest groups (Priante et al., 2017). Alongside the strengths that the digital mode of communication clearly has, i.e., well-timed and faster transfer of information (Collyer, 2017), change management and decision making, faster response to the problem and feedback (Akan et al., 2016), scientists also discuss other aspects of CMC. One of the most important is the need to communicate different than before, as global and dynamic business environments, the transition to a network organization structure, and the introduction of the $\mathrm{Z}$ generation into the labor market require new answers on how to maintain an effective interaction between organizations, groups and individuals. Based on the research, scientists provide reasonable suggestions for overcoming the challenges of modern organizations of communication and social challenges (social integration, education). However, the insights to the scientific literature summarizing recent research are relatively rare, making it difficult for practitioners in organizations to make use of researchers' observations. Filling in this gap, the aim of the article is to examine recent scientific publications in which the concept of CMC is analyzed in relation to the activities of organizations, and to highlight issues that lead to a better understanding of topical issues.

This scoping review, based on methodological access, is intended for practitioners interested in cutting-edge research on the application of ICT in the field of communication in organizations as well as researchers conducting research on related topics such as organizational behavior, other related research areas.

Due to the nature of investigation, the article is not presenting pure theoretical background, instead it immediately presents the methodological part where a general overview of recent scientific research is conducted. Following is the part of the research results. At the end of the article, key conclusions are formulated.

\section{Research methodology}

Research methodology of the present article is based on the scoping review and is implemented in accordance to the suggested framework by Arksey and O'Malley (Peterson, 2016). The usage of this method leads to a qualified and proper meta-analysis and synthesis of the main evidence in the context of CMC implication in the management process of modern organizations. The procedure of scoping review was conducted by following four step guidelines as follows:

1. Quick overview in the field of related research. It consists of identifying the most dominant keywords, research topics, widespread in different types of organizations and management processes, fields of effect. At this point main database and other research indicators were:

- Search database: free access web search engine Google Scholars, scientific information analytics site Elsevier, and Academic Search Complete via EBSCOhost (by using a personal Mykolas Romeris University student account);

- Search period: 2015-2018; 
- Main findings by the keyword Computer Mediated Communication: Google Scholars 620 findings; Elsevier - 55 findings; Academic Search Complete via EBSCOhost - 137. In total -812 records. After categorization and segmentation in the third step - 39 proper records left for further investigation and analyses. In detail, results eliminated were: 133 records in total excluded as duplicates (entries by unique authors only); 508-not relevant topic and content or only abstracts; 31-due to language limitations; 48 - due to type of publication; 14 - due to using only case study method (limited implication).

- The main criteria for the elimination: too narrow and specific research topic; based only on a case study method, which leads to a limited implication of findings; only an abstract but not the whole article written in the English language; only one article by the same researcher or their group; article published in a scientific journal, not in periodical publications or webpages.

2. Secondly, the preliminary assessment of relevance and possibilities for conducting a full systematic review was made. In relation to the type and aim of the present article, main fields for future research and the need for them were considered without deep analyses. Therefore, the main general topics were identified: research of practical implementation in Public and Non-governmental sector, comparative analyses between different type of organizations, creation of implementation guidelines and afterward a so-called Evaluation Model, relation and combination with traditional project and process management methods, and overall improvement-optimization, Change Management strategies and activities.

3. A so called focused synthesis was used as a following step in the scope review of this article. In this stage the additional methods of categorization and segmentation into groups were used by the author. The overall result of this stage was 2 groups of research objects and selection of 6 leading keywords:

- Group of Primary focus objects. They are described by using Computer Mediated Communication, organization and communication management, information and communication technologies (ICT) and Communication terms;

- Group of Secondary focus object. It consists of analyses of articles where dominated combinations are: Human Resource Management (HRM) and Communication, leadership and Communication, and technostress and Communication, online learning.

4. Finally, identifying key points and drawing conclusions of the application of ICT and Internet technology in the context of modern organization communication, related management processes, and system usage were made.

The whole above described procedure of research can be documented and mapped in a similar format as used in the PRISMA (Preferred Reporting Items for Systematic Reviews and Meta-Analysis) model (Figure 1). 


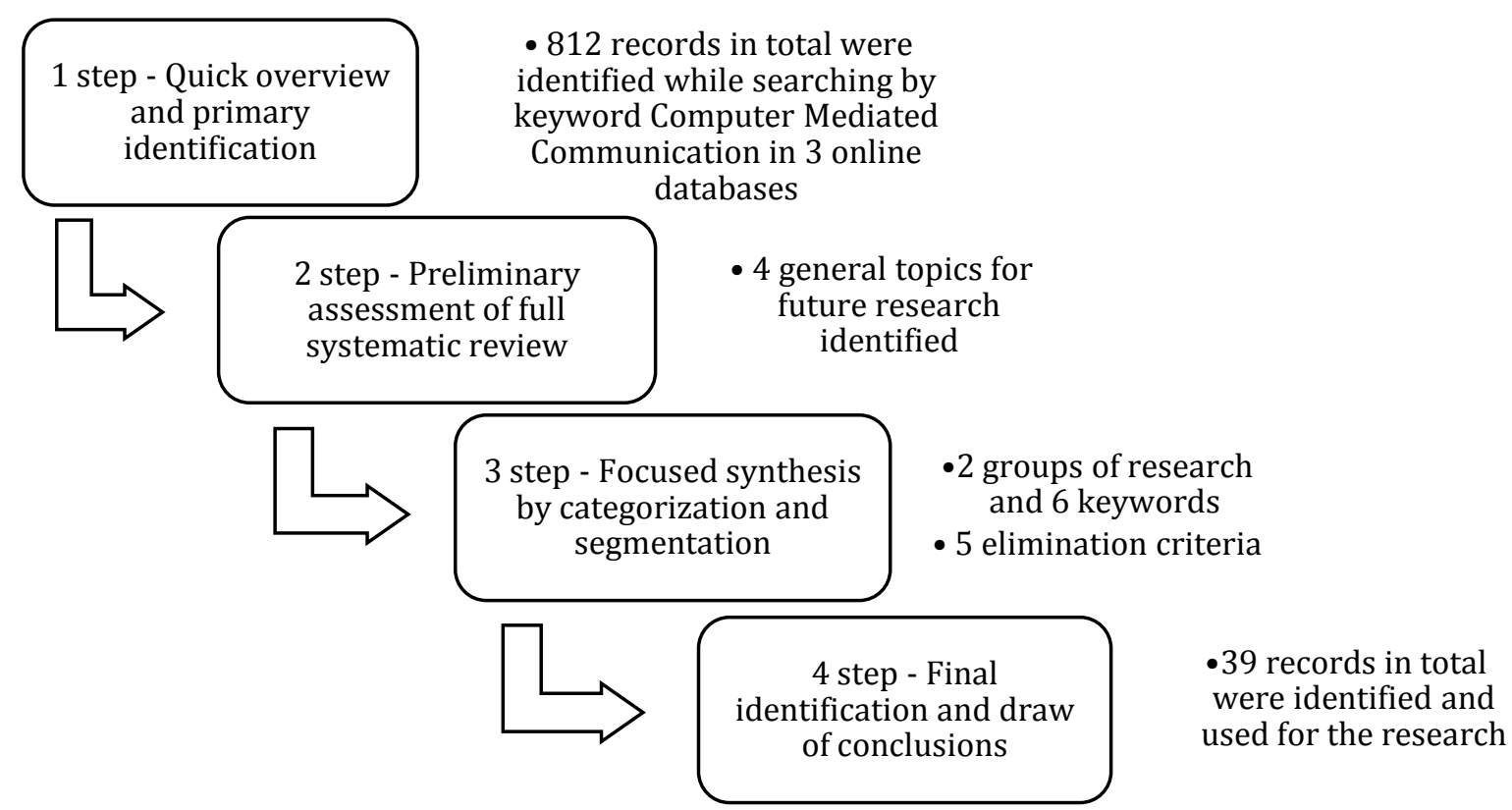

Source: the author

Figure 1. Flowchart and key details of the research procedure

\section{Results: research directions on CMC application in organizations}

As regards the direction of research in the application of CMC in organizations, it can be noted that in recent years researchers have mostly focused on:

a) CMC's challenges in organizational (team) and individual work contexts (e.g. CMC's impact on the employee's welfare and health, use of social networks to meet organizational goals and shape the organization's image, enhancing organizational culture and employee's identity, etc.);

b) Application of CMC to increase the efficiency of organizational management (e.g. employee engagement, leadership, change management, project management, meeting management, team collaboration, etc.);

c) Application of CMC to developing external communication, such as public relations;

d) ICT feasibility studies (e.g. use of social media for employee interaction and collaboration, opportunities for using new smart devices in social integration, education, etc.).

These directions will be discussed in more detail further.

\section{Challenges of CMC in the context of the organization's activities and individual work}

Challenges for the use of CMC in the context of organizations' activities and individual work are wide-ranging, but in the light of recent research, certain specific challenges can be identified in this context.

First of all, it is the challenges of employee diversity and leadership. Organizations are facing a new type of problems. While training and integration of young professionals and conveyance of senior employee's experience have been discussed earlier, organizations are now faced with the need for universal and continuing education. One has to consider the fact that modern technologies are closer to a certain profile of employees, according to age and 
technology experience. Meanwhile, work experience in a specific field of activity is no longer such a significant advantage and is increasingly fading to the second plan. For this reason, the attitude of leadership and the necessary leadership abilities of the leader are also changing. Modern leadership is often understood as the involvement and example of managerial staff, the ability to prepare the organization to function in a changing environment (Bucăța, Rizescu, 2017). Here, the crucial issue of the nature of ICT is emphasized. The most significant challenge facing organizations more or less is information overload, resulting in a very high amount of information that an employee is unable to process properly due to a lack of time. Another challenge is the feature overload, described as a situation where the employee does not have necessary skills and knowledge to use the appropriate technical equipment at the workplace. The third aspect of CMC implementation in organizations is communication overload, which does not allow sufficiently careful processing of the information received and misses focus on quality of work. (Saunders et al., 2017; Tarafdar et al., 2017). In addition, employees are stressed and dissatisfied with the fact that by using modern communication technologies leaders can monitor the execution of tasks more closely. In some cases, employees regard it as a disturbance of privacy both in the working environment and in their private life, especially when work goes into leisure time and vice versa (Bianca, 2017; Kapucu, Haupt, 2016; Musah Adiza, 2016; Chory et al., 2015).

Another specific CMC challenge is the agility aspect. Agility is commonly associated with the organization's ability to integrate, modify or synchronize internal and external business processes, considering the dynamics of the environment. However, as far as organizational communication is concerned, agility is associated with the high level of detail information inherent in the operation of IT systems and the corresponding need for structuring and detailing working information that adds additional burden to employees and requires them to take appropriate care of the communication process (Park et al., 2017; Sueldo, 2016). In other words, technology not only facilitates communication, it also complicates it, because it requires employees to have a specific knowledge and skills to provide and maintain the required information in an appropriate format and detail.

CMC inspires not only the need to work differently for individuals, both employees and leaders, but also the specifics of teamwork. Remote work comes into force, thus resulting that often team members have never interacted eye to eye. Naturally, this creates the need for a different, new teamwork culture, and so on. (Espinosa et al., 2015; Ai He et al., 2017). At the same time, more attention is paid to such phenomena or situations as inequal access to information or not well-timed presentation to the team, lack of consensus, disagreement on terms, work, or even communication forms and channels. All this complicates the decisionmaking processes in organizations, which is why some workers are confronted with resistance to CMC (Gutiérrez-Santiuste et al., 2016).

All of the mentioned CMC challenges to the employees and leadership combine the widespread phenomenon of technostress. Technostress is the stress of employees due to the unmanageable amount of information and related work tasks accompanied by short deadlines for assigning tasks. Technostress manifests itself in a variety of autonomous and personally conscious resistance forms of the worker's body (Akan, 2016). Technostress in the long run determines the general physiological deterioration of health, increased psychological stress and the expression of negative emotions (Atanasoff, Venable, 2017). As a result, the challenges of CMC and ICT should not be ignored or evaluated as the characteristics of the organizational environment determined by the era, non-targeted solutions. 


\section{Application of CMC by increasing efficiency of organization management}

The previous sub-section shows that information technology poses significant challenges to individuals in organizations. However, CMC is recognized as one of the tools for assessing technologies when measuring not by individuals but by groups, which enables them to increase the efficiency of organizations, improve decision-making and teamwork, etc. (Bahmani, 2018; Pang, 2018; Carlson, 2013; Rashiti et al., 2015; Kiatsuranon, Suwunnamek, 2017).

Before discussing these and other aspects in more detail, an insight by Espinosa et al. (2015) is worth mentioning that nowadays, Face-to-Face communication is no longer the most appropriate option for global groups or organizations and organizations where groups in different locations work simultaneously. The impact of CMC on organizational management firstly reveals itself as an opportunity to unify the involvement of organization's employees into the organization, increase the accuracy of self-reflection and information received. On the other hand, while working and communicating in virtual teams, aspects of overloading tasks and time-consuming tasks remain important. ICT allows sending, receiving, transferring and technical processing of extremely large amounts of information, thus resulting in additional managerial problems of a psychological and behavioral nature. In organizations, it is expected for the responsible ones in all management units to accept considered and more risky solutions, just because they have a large amount of information. Unfortunately, when comparing the amount of information to the time it takes to make decisions, it becomes obvious that the time perspective is so limited that there is no theoretical possibility not only to consider, but also to reconcile decisions between all the interested parties. Furthermore, when accountable people are exposed to large amounts of new information and revisions, there is a reasonable doubt about the correctness of the decisions made. There is no certainty that decision-makers took time to evaluate all the data provided, consider last minute changes and ensure that all interested parties have the same information on the matter (Espinosa, 2015).

However, with the organization as a whole, digital communication management in today's organizations can be considered as a mean to increase the organization's brand value and create a strong identity and a new type of emotional relationship with its clients (Dua, 2017; Blackbourn et al., 2018; Blidaru, 2015; Patrutiu-Balte, 2016) (Table 1).

Table 1. CMC in developing organizational relationships with customers

\begin{tabular}{|c|l|}
\hline $\begin{array}{c}\text { CMC application } \\
\text { field }\end{array}$ & \multicolumn{1}{c|}{ Notes } \\
\hline $\begin{array}{c}\text { Positioning and } \\
\text { formation of } a \\
\text { brand }\end{array}$ & $\begin{array}{l}\text { A positive image of the organization in the eyes of customers is important for achieving } \\
\text { goals and sustainability of the organization. There are 3 possible forms towards image } \\
\text { and position formation: instrumental (information transfer function), communication } \\
\text { (function of communication creation) and validating (norm / value consolidation } \\
\text { function) (Chaudhri, 2016). }\end{array}$ \\
\hline $\begin{array}{c}\text { Creating and } \\
\text { maintaining } \\
\text { customer } \\
\text { relationships }\end{array}$ & $\begin{array}{l}\text { In the context of a technologically advanced communication, not only the function of } \\
\text { information conveyance but also the creation of an open, continuous feedback-based } \\
\text { system is discussed. The use of ICT ensures a prompt and constructive dialogue with } \\
\text { customers, thus reducing the risk of failure-breakdown (Collyer, 2016). }\end{array}$ \\
\hline $\begin{array}{c}\text { Analysis and } \\
\text { formation of habits }\end{array}$ & $\begin{array}{l}\text { CMC is used to shape consumer habits, from building trust to the brand to ending with } \\
\text { emotional engagement with customers. In this context, following key areas of } \\
\text { organizational leadership are highlighted: knowledge on brand; knowledge about } \\
\text { customers; relevant communication tools shaped by the emotional factor; a strategy to } \\
\text { impart emotion (Dua, 2017; Tandazo et al., 2016). }\end{array}$ \\
\hline
\end{tabular}

Source: the author 
Bearing in mind that organization's employees are also considered as being [internal] clients, CMC enables the creation and maintenance of a widespread communication network that operates on a regular basis and provides management with a variety of opportunities. These opportunities include a better understanding of business processes, needs of users and employees, problems, attracting new employees, as well as shaping market and individual consumption segments and, in general, influencing the organization's goals.

\section{CMC application by developing public communication for the organization}

The application of CMC through the development of external communication of the organization is one of the main directions of recent research. It is to be held that the use of ICT is an integral part of the communication process in today's networking organizations, regardless of their type of activity. Additionally, considering aspects such as characteristics of the generation $\mathrm{Z}$, which now is rather new to the market, and increasingly intuitive ICT itself, it is stated that technological development promotes the change of communication processes and practices in organizations, especially in fields of public relation and business partnership. Therefore, the needs of organizations do not affect technological advancements as they used to do (Pang et al., 2018).

Researchers investigating public relations in various organizations point out those not necessarily large and advanced business organizations are the best example of the effectiveness of external communication. Public sector institutions, such as those at the level of EU government, or even certain organized groups such as the Islamic State, are capable of exerting a particular impact on the public through various channels of digital communication (Granda, 2016; Bole, Kallmyer, 2016). Bole and Kallmyer (2016) have analyzed how organizations combine CMC and network-enabled social media features and create a targeted, audience-oriented communication strategy and formulated the following components of effective public organizational communication:

1. The use of social media, social networks and smart-mobile devices;

2. Great knowledge of the target audience and the most accurate knowledge of the localization;

3. Interactive and visual material, involving direct communication and active contact with the audience;

4. Specific and simple message content with a clearly expressed emotional or ideological basis.

As seen above, organizations' public communication has certain features of mass communication. The most important of those is the simulation of personal and interpersonal communication in order to create a close emotional trust relationship with everyone in the audience.

\section{Features of the research on CMC challenges}

Analyzing the recent scientific discourse, it can be summarized that a broad CMC topic (Table 2) is most often developed in four areas of CMC research. These are:

- Training of employees through ICT and CMC capabilities;

- The internal organizational environment and related processes in order to adapt to CMC challenges;

- External organizational environment and related processes in the context of CMC opportunities;

- The overall impact of ICT and CMC on organizations and the general public. 
Table 2. Concept of CMC in the current scientific literature

\begin{tabular}{|c|c|c|c|c|c|}
\hline$\dot{0}$ & Author(s) & Year & Area of CMC researched & $\begin{array}{l}\text { Research } \\
\text { methodology }\end{array}$ & $\begin{array}{l}\text { Research } \\
\text { prospects } \\
\text { proposed }\end{array}$ \\
\hline 1. & $\begin{array}{l}\text { Atanasoff, L., } \\
\text { Venable, M. }\end{array}$ & 2017 & $\begin{array}{l}\text { The negative impact of information and } \\
\text { communication technologies on employees' well- } \\
\text { being and physical health, connection with } \\
\text { technostress (prevention and intervention) }\end{array}$ & $\begin{array}{l}\text { Analysis of } \\
\text { scientific } \\
\text { literature }\end{array}$ & No \\
\hline 2. & Baltes- Patrutiu, L. & 2016 & $\begin{array}{l}\text { Adaptation of technology-oriented communication } \\
\text { strategies and tools and their compatibility with } \\
\text { the organization's sales strategy, expression in IT } \\
\text { profile organizations in Romania }\end{array}$ & $\begin{array}{l}\text { Focus group } \\
\text { discussion }\end{array}$ & No \\
\hline 3. & $\begin{array}{l}\text { Espinosa J. A., Nan } \\
\text { N. Carmel E. }\end{array}$ & 2015 & 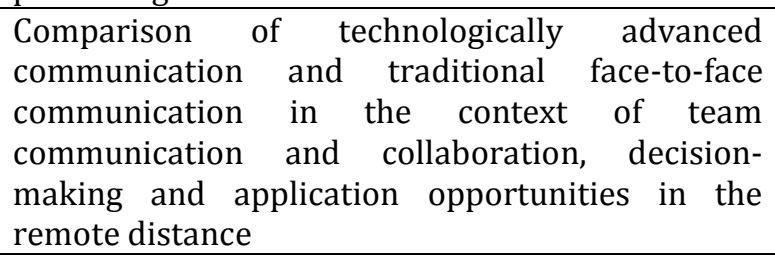 & $\begin{array}{l}\text { Analysis of } \\
\text { scientific } \\
\text { literature }\end{array}$ & No \\
\hline 4. & $\begin{array}{l}\text { Bole, R., Kallmyer, } \\
\text { K. }\end{array}$ & 2016 & $\begin{array}{l}\text { Technological adaptation of the communication } \\
\text { tools and the Internet network platform in } \\
\text { external organizational communication, an } \\
\text { expression in public sector organizations in the } \\
\text { United States }\end{array}$ & Case study & No \\
\hline 5. & $\begin{array}{l}\text { Bucăța, G., Rizescu, } \\
\text { A.M. }\end{array}$ & 2017 & $\begin{array}{l}\text { Application of organizational communication in } \\
\text { management functions, strategic planning and } \\
\text { involvement of employees in the organization, } \\
\text { compatibility with organizational culture }\end{array}$ & $\begin{array}{l}\text { Analysis of } \\
\text { scientific } \\
\text { literature }\end{array}$ & No \\
\hline 6. & Chaudhri, V. & 2016 & $\begin{array}{l}\text { Technologically adapted communication tools and } \\
\text { strategy and compatibility with corporate social } \\
\text { responsibility, image formation }\end{array}$ & Interview & No \\
\hline 7. & Collyer, S. & 2016 & $\begin{array}{l}\text { The expression and importance of organizational } \\
\text { communication in project management }\end{array}$ & $\begin{array}{l}\text { Analysis of } \\
\text { scientific } \\
\text { literature; } \\
\text { Focus group; } \\
\text { Interview }\end{array}$ & Yes \\
\hline 8. & Dua, S. & 2017 & $\begin{array}{l}\text { Manage and the use of technologically-oriented } \\
\text { communication in the external communication of } \\
\text { the organization, creation and support of } \\
\text { customer relations }\end{array}$ & $\begin{array}{l}\text { Analysis of } \\
\text { scientific } \\
\text { literature }\end{array}$ & No \\
\hline 9. & $\begin{array}{l}\text { Granda T.C.V., } \\
\text { Paladines G.F., } \\
\text { Velásquez B.A. }\end{array}$ & 2016 & $\begin{array}{l}\text { Adaptation of technologically advanced } \\
\text { communication tools to the strategy and } \\
\text { improvement of public sector organizations' } \\
\text { activities, communication with customers }\end{array}$ & Survey & No \\
\hline 10. & $\begin{array}{l}\text { Liudwig, S., Laer, } \\
\text { Van T., Ruyter, De, } \\
\text { K., Friedman, M. }\end{array}$ & 2016 & $\begin{array}{l}\text { The clarity and applicability of technologically } \\
\text { advanced communication tools and problems in } \\
\text { internal and external communication of } \\
\text { organizations, decision-making }\end{array}$ & Case study & Yes \\
\hline 11. & McLean, K.J. & 2016 & $\begin{array}{l}\text { Use of information and communication } \\
\text { technologies and technologic communication tools } \\
\text { in the learning process, new learning } \\
\text { opportunities and problems }\end{array}$ & $\begin{array}{l}\text { Analysis of } \\
\text { scientific } \\
\text { literature }\end{array}$ & No \\
\hline 12. & $\begin{array}{l}\text { Mejias, R. J., Reinig, } \\
\text { B. A., Dennis, A. R., } \\
\text { MacKenzie, S. B. }\end{array}$ & 2017 & $\begin{array}{l}\text { The impact of technologically advanced } \\
\text { communication on employee engagement and } \\
\text { decision-making in teamwork }\end{array}$ & Experiment & Yes \\
\hline
\end{tabular}




\begin{tabular}{|c|c|c|c|c|c|}
\hline$\dot{0}$ & Author(s) & Year & Area of CMC researched & $\begin{array}{l}\text { Research } \\
\text { methodology }\end{array}$ & $\begin{array}{l}\text { Research } \\
\text { prospects } \\
\text { proposed }\end{array}$ \\
\hline 13. & $\begin{array}{l}\text { Park, Y., A. El } \\
\text { Sawy, O., Fiss, P.C. }\end{array}$ & 2017 & 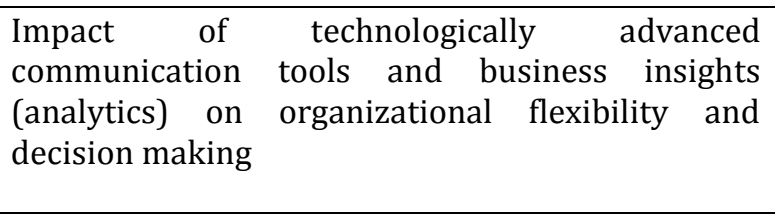 & $\begin{array}{l}\text { Analysis of } \\
\text { scientific } \\
\text { literature; } \\
\text { Case study; } \\
\text { Survey }\end{array}$ & Yes \\
\hline 14. & $\begin{array}{l}\text { Parke, K., Marsden, } \\
\text { N., Connolly, C. }\end{array}$ & 2017 & $\begin{array}{l}\text { Compatibility and application of technologically } \\
\text { advanced communication tools and distance } \\
\text { learning }\end{array}$ & $\begin{array}{l}\text { Analysis of } \\
\text { scientific } \\
\text { literature; } \\
\text { Qualitative } \\
\text { content } \\
\text { analysis; } \\
\text { Case study }\end{array}$ & No \\
\hline 15. & $\begin{array}{l}\text { Saunders, C., } \\
\text { Wiener, M., Klett, } \\
\text { S., Sprenger, S. }\end{array}$ & 2017 & $\begin{array}{l}\text { The negative impact of the use of technologically } \\
\text { advanced communication tools on employees' } \\
\text { health and well-being at work, the connection } \\
\text { with the technostress }\end{array}$ & Survey & Yes \\
\hline 16. & $\begin{array}{l}\text { Schumann,S., } \\
\text { Klein, O., Douglas, } \\
\text { K., Hewstone, M. }\end{array}$ & 2017 & $\begin{array}{l}\text { The clarity and application of technologically } \\
\text { advanced communication in the formation of } \\
\text { behavior and opinion of social groups }\end{array}$ & Experiment & Yes \\
\hline 17. & $\begin{array}{l}\text { Song Y., } \\
\text { Kong S.C. }\end{array}$ & 2017 & $\begin{array}{l}\text { The use of private information and } \\
\text { communication technologies in the learning } \\
\text { process and at work, new learning opportunities } \\
\text { and problems }\end{array}$ & $\begin{array}{l}\text { Analysis of } \\
\text { scientific } \\
\text { literature; } \\
\text { Observation; } \\
\text { Content } \\
\text { analysis } \\
\end{array}$ & No \\
\hline 18. & Taylor, A. M. & 2016 & $\begin{array}{l}\text { The adaptation of technologically advanced } \\
\text { communication and its tools in the learning } \\
\text { process (second language) }\end{array}$ & Meta-analysis & No \\
\hline 19. & $\begin{array}{l}\text { Tarafdar M, } \\
\text { Cooper CL, Stich J- } \\
\text { F. }\end{array}$ & 2017 & $\begin{array}{l}\text { The negative impact of the use of information and } \\
\text { communication technologies on employees' health } \\
\text { and well-being at work, connection with } \\
\text { technostress, its forms }\end{array}$ & $\begin{array}{l}\text { Analysis } \\
\text { scientific } \\
\text { literature }\end{array}$ & Yes \\
\hline 20. & Ziegler, N. & 2015 & $\begin{array}{l}\text { Technologically advanced communication and its } \\
\text { impact on employee skills development, learning } \\
\text { (second language) }\end{array}$ & $\begin{array}{l}\text { Analysis of } \\
\text { scientific } \\
\text { literature; } \\
\text { Meta- } \\
\text { analysis; } \\
\text { Case study } \\
\end{array}$ & Yes \\
\hline 21. & $\begin{array}{l}\text { Rouhshad, A., } \\
\text { Wiggles-worth, G., } \\
\text { Storch. N. }\end{array}$ & 2016 & $\begin{array}{l}\text { Negotiations through different forms of } \\
\text { communication: comparison between face-to-face } \\
\text { communication and technologically advanced } \\
\text { communication }\end{array}$ & $\begin{array}{l}\text { Case studies; } \\
\text { Comparative } \\
\text { analysis }\end{array}$ & Yes \\
\hline 22. & $\begin{array}{l}\text { Carlson, J., Carlson, } \\
\text { D., Hunter, E., L. } \\
\text { Vaughn, R., } \\
\text { George, J }\end{array}$ & 2015 & $\begin{array}{l}\text { The influence of technologically advanced } \\
\text { communication on the effectiveness of teamwork }\end{array}$ & $\begin{array}{l}\text { Survey; } \\
\text { Regressive } \\
\text { analysis }\end{array}$ & Yes \\
\hline 23. & $\begin{array}{l}\text { Gutiérrez- } \\
\text { Santiuste, E., } \\
\text { Gallego-Arrufat, } \\
\text { M.J., Simone, A. }\end{array}$ & 2016 & $\begin{array}{l}\text { Applications and barriers of technologically } \\
\text { advanced communication to online learning (e- } \\
\text { learning) }\end{array}$ & $\begin{array}{l}\text { Case study; } \\
\text { observation; } \\
\text { Comparative } \\
\text { analysis }\end{array}$ & Yes \\
\hline 24. & $\begin{array}{l}\text { Hung,Y. W., } \\
\text { Higgins S. }\end{array}$ & 2016 & $\begin{array}{l}\text { Use of information and communication } \\
\text { technologies and technologically advanced } \\
\text { communication tools in the learning process, new } \\
\text { learning opportunities }\end{array}$ & $\begin{array}{l}\text { Experiment; } \\
\text { Observation; } \\
\text { Survey }\end{array}$ & Yes \\
\hline
\end{tabular}




\begin{tabular}{|c|c|c|c|c|c|}
\hline$\dot{2}$ & Author(s) & Year & Area of CMC researched & $\begin{array}{c}\text { Research } \\
\text { methodology }\end{array}$ & $\begin{array}{l}\text { Research } \\
\text { prospects } \\
\text { proposed }\end{array}$ \\
\hline 25. & $\begin{array}{l}\text { Chory, R., E. Vela, } \\
\text { L., A. Avtgis, T. }\end{array}$ & 2015 & $\begin{array}{l}\text { The negative impact of technologically advanced } \\
\text { communication tools on employees' privacy and } \\
\text { well-being at work, manifestations of } \\
\text { technostress, connection to loyalty to organization }\end{array}$ & $\begin{array}{l}\text { Experiment; } \\
\text { Observation; } \\
\text { Survey }\end{array}$ & Yes \\
\hline 26. & $\begin{array}{l}\text { Rashiti, S. G., } \\
\text { Ramadani, V., } \\
\text { Abazi-Alili, H., } \\
\text { Dana, L. P., Ratten, } \\
\text { V. }\end{array}$ & 2015 & $\begin{array}{l}\text { The impact of information and communication } \\
\text { technologies on the innovation and performance } \\
\text { of business organizations }\end{array}$ & Survey & No \\
\hline 27. & $\begin{array}{l}\text { Pang, A.; Shin, W.; } \\
\text { Lew, Z.; Walther, J. } \\
\text { B. }\end{array}$ & 2018 & $\begin{array}{l}\text { Application of information and communication } \\
\text { technologies for public communication and } \\
\text { business partnership within the organization and } \\
\text { between different organizations, creation of two- } \\
\text { way communication }\end{array}$ & Case study & No \\
\hline 28. & $\begin{array}{l}\text { Kapucu, N., Haupt, } \\
\text { B. }\end{array}$ & 2016 & $\begin{array}{l}\text { The use of information and communication } \\
\text { technologies in public sector organizations in the } \\
\text { United States and the link with citizens' data } \\
\text { security }\end{array}$ & $\begin{array}{l}\text { Analysis } \\
\text { scientific } \\
\text { literature }\end{array}$ & No \\
\hline 29. & $\begin{array}{l}\text { Bahmani, K., } \\
\text { Semnani-Azad, Z., } \\
\text { Adair, W. L., } \\
\text { Sycara, K. }\end{array}$ & 2018 & $\begin{array}{l}\text { Application of technologically advanced } \\
\text { communication and impact on inter-group } \\
\text { communication and negotiations in organizations }\end{array}$ & $\begin{array}{l}\text { Experiment, } \\
\text { observation, }\end{array}$ & Yes \\
\hline 30. & $\begin{array}{l}\text { Rains, S.A., } \\
\text { Brunner, S.R. } \\
\text { Akers, C., } \\
\text { Pavlich, C.A., } \\
\text { Goktas, S, }\end{array}$ & 2017 & $\begin{array}{l}\text { The negative impact of technological } \\
\text { communication on personal identity, actions and } \\
\text { overall emotional conditions in the context of } \\
\text { organizations and society }\end{array}$ & $\begin{array}{l}\text { Conceptual } \\
\text { modeling }\end{array}$ & No \\
\hline 31. & $\begin{array}{l}\text { Priante, A., } \\
\text { Ehrenhard, M., van } \\
\text { den Broek, T., } \\
\text { Need, A. }\end{array}$ & 2017 & $\begin{array}{l}\text { The impact of technological communication and } \\
\text { social media on personal identity and collective } \\
\text { action in organizations and society, review of } \\
\text { scientific literature (2012-2016) and trends in } \\
\text { future research }\end{array}$ & $\begin{array}{l}\text { Analysis of } \\
\text { scientific } \\
\text { literature; } \\
\text { descriptive } \\
\text { and thematic } \\
\text { analysis }\end{array}$ & Yes \\
\hline 32. & $\begin{array}{l}\text { Ai He, H., } \\
\text { Yamashita, N., } \\
\text { Wacharamanotha } \\
\text { m, C., Horn, A., } \\
\text { Schmid, J., M } \\
\text { Huang, E. }\end{array}$ & 2017 & $\begin{array}{l}\text { Adaptation of technologically advanced } \\
\text { communication tools to solve problem situations } \\
\text { due to differences in in terms of culture among } \\
\text { teams operating in different locations }\end{array}$ & $\begin{array}{l}\text { Experiment, } \\
\text { observation }\end{array}$ & No \\
\hline 33. & Bianca, I. & 2017 & $\begin{array}{l}\text { The impact of information and communication } \\
\text { technologies and the platform on employees' } \\
\text { safety and privacy at work; personal data security } \\
\text { management }\end{array}$ & Interview & No \\
\hline 34. & $\begin{array}{l}\text { Blackbourn, J. M., } \\
\text { Fillingim, J. F., } \\
\text { Thomas, C., } \\
\text { McClelland, S. } \\
\text { Payne, J. S }\end{array}$ & 2018 & $\begin{array}{l}\text { Choices of the organization's communication } \\
\text { strategy and alignment with ensuring feedback } \\
\text { and continuous improvement of processes in } \\
\text { organizations }\end{array}$ & $\begin{array}{l}\text { Analysis } \\
\text { scientific } \\
\text { literature }\end{array}$ & No \\
\hline 35. & $\begin{array}{l}\text { Kiatsuranon, K., } \\
\text { Suwunna-mek, } 0 .\end{array}$ & 2017 & $\begin{array}{l}\text { Adaptation of information and communication } \\
\text { technologies and technologically advanced } \\
\text { communication to acquire competitive advantage } \\
\text { of organizations, training and attracting } \\
\text { employees to the organization }\end{array}$ & Survey & No \\
\hline 36. & $\begin{array}{l}\text { Akan, B., Er Ülker, } \\
\text { F., Ünsar, A.S. }\end{array}$ & 2016 & $\begin{array}{l}\text { Adapting communication strategies and tools of } \\
\text { contemporary organizations to organizational } \\
\text { change and personnel management }\end{array}$ & Survey & Yes \\
\hline
\end{tabular}




\begin{tabular}{|c|c|c|c|c|c|}
\hline$\dot{0}$ & Author(s) & Year & Area of CMC researched & $\begin{array}{l}\text { Research } \\
\text { methodology }\end{array}$ & $\begin{array}{l}\text { Research } \\
\text { prospects } \\
\text { proposed }\end{array}$ \\
\hline 37. & $\begin{array}{l}\text { Anghel B. D.M., } \\
\text { Anghel B. G. R. }\end{array}$ & 2015 & $\begin{array}{l}\text { The forms, interruptions and possibilities for } \\
\text { improving the communication of modern } \\
\text { organizations }\end{array}$ & $\begin{array}{l}\text { Analysis } \\
\text { scientific } \\
\text { literature }\end{array}$ & No \\
\hline 38. & $\begin{array}{l}\text { Musah Adiza, A., } \\
\text { Zulkipli, G., } \\
\text { Ahmad, N.S.I. }\end{array}$ & 2017 & $\begin{array}{l}\text { Relationship between organizational } \\
\text { communication and job satisfaction }\end{array}$ & $\begin{array}{l}\text { Analysis of } \\
\text { scientific } \\
\text { literature; } \\
\text { Survey }\end{array}$ & No \\
\hline 39. & Sueldo, M. & 2016 & $\begin{array}{l}\text { Compatibility of corporate communication and } \\
\text { strategic organization management, relationship } \\
\text { with social responsibility; management of internal } \\
\text { and external stakeholders }\end{array}$ & $\begin{array}{l}\text { Semi- } \\
\text { structured } \\
\text { interview }\end{array}$ & No \\
\hline
\end{tabular}

Source: the author

Although the task of detailing the latest issues of CMC research in the article is not raised, in answering the purpose of the article it is necessary to emphasize the most commonly discussed issue among scientists in each of the CMC research areas:

1. Employee training using capabilities of ICT and CMC. Studies of employee training show that the development of globalization and the so-called technological revolution are subject to specific training and learning needs. If it has been important for organizations to have high professional and team-building skills so far, it is becoming increasingly important for mid-level managers and international advisers to know at least a few foreign languages to expand their geography. For this aim, various ICT tools and programs are particularly useful. So, in scientific publications there is an increasing number of keywords such as computer assisted language learning (CALL), second language acquisition (SLA), etc. The benefits of ICT in language teaching are written by, for example, Ziegler (2015), Hung, Higgins (2016), Rouhshad et al. (2016), Song, Kong (2017) et al.

2. The internal organizational environment and related processes when aiming to adapt to challenges raised by CMC. Researchers in these research topics discuss the use of ICT in complex communication or conflict-based communication: the role of CMC in team building and decision-making, the impact of CMC on organizational culture and leadership, change management, etc. (Bradley, Cambell, 2014; Bucăța, Rizescu, 2017; Berry, 2006; Kapucu, Hu, 2014).

3. External organizational environment and related processes in the context of CMC opportunities. Researchers in this topic are exploring what the strategic level of communication among public organizations should be, using the web-based platform and smart mobile devices. Other researchers associate external communication with marketing rather than public relations and try to find answers to such questions as, for example, how ICT and CMC can help at shaping a positive image of an organization, which technological communication solutions can better integrate and adapt to e-marketing and / e-commerce strategies and methods, etc. (Tandazo et al., 2016; Chaudhri, 2016; Baltes- Patrutiu, 2016; Dua, 2017).

4. The overall impact of ICT and CMC on organizations and the general public. The spectrum of research on the impact of ICT and CMC on society and organizations is particularly broad. Emphasis is on aspects such as:

- The prevalence of the phenomenon of technology and the negative impact of technology on employee well-being; 
- Due to the technology, depersonalized, but at the same time, customized (personalized) communicative influence on shaping the opinion of consumers and the nature of consumption;

- The influence of technologies on spreading propaganda, ideological information in society. It also deals with cases of distortion of information and deliberate misrepresentation of the audience through the use of digital communication channels and corresponding funding schemes for the creation of a communication space;

- Solving public problems with the help of ICT and CMC. On the subject of public education and training, there is a developing research on the use of CMC to improve the integration of social exclusion and risk groups (e.g. refugees) through online learning and digital mentorship. In addition, the efficiency of remote learning is widely researched (e.g., Atanasoff, Venable, 2017; Bole, Kallmyer, 2016; Liudwig et al., 2016; Hansson et al., Andrade, Doolin, 2016; Parkel et al., 2017; Taylor, 2016).

When discussing the latest CMC research, it is also noted that it is mostly focused on research in the real workplace by interviewing staff responsible for communication processes and senior personnel. Also, part of the research is based on monitoring trends in the use of ICT and the internet platform. And the fact that the CMC construct is not yet fully up-to-date is backed up by a considerable amount of literature in the nature of reviews and concept reviews.

Finally, it can be noted that since CMC's problem area is rather new compared to traditional communication research, a large proportion of researchers talk about the limitations of research and the need for future research as well (Table 2). However, specific topics or issues have not been resolved. Researchers often highlight our already mentioned CMC challenges.

\section{Conclusions}

Research of CMC in the current scientific discourse are pointed to highlight ICT and CMC challenges in contexts of inter-organizational, organizational, group (team) and inter-personal communication as well as to discuss a possibility to influence the opinion and behavior of customers and even society with the help of ICT.

An analysis of publications selected has shown that the concept of CMC is very broad; therefore, in the future it is recommended to narrow and specify the area towards one of the scoping review by choosing to consider communication in relation to these fields as follows: HRM, leadership, remote work and team management, organization of work processes, training and learning, interpersonal relations, sales, consumer behavior and marketing, public relations, the formation of public opinion and provisions, the possibilities of adapting the communication technologies, etc. Due to the diversibility of the applicability of the CMC concept, each of the mentioned areas would be significant and very useful to analyze to a more detailed manner.

Finally, the CMC scoping review has shown that researchers' focus on research in this area is not diminishing, which is why it is still important for the scientific community not to be reserved but to share insights with practitioners who are interested in applying scientific knowledge to improve the efficiency of the performance of organizations.

\section{References}

1. Ai He H., Yamashita N., Wacharamanotham C., Horn A., Schmid J., M Huang E. (2017) Two Sides to Every Story: Mitigating Intercultural Conflict through Automated Feedback and Shared Self-Reflections in Global Virtual Teams. Journal Proceedings of the ACM on Human-Computer Interaction, Vol. 51, No. 1: 1. 
2. Akan B., Er Ülker F., Ünsar A.S. (2016) The effect of organizational communication towards resistance to change: a case study in banking sector. Economic Review: Journal of Economics \& Business, Vol. 14, No. 1: 53; 59; 64-65.

3. Anghel B.D.M., Anghel B.G.R. (2015) Organizational Communication Forms and Causes for Disruption of Organizational Communication and their Improvement. Valahian Journal of Economic Studies, Vol. 6, No. 1: 37; 43.

4. Atanasoff L., Venable M. (2017) Technology and Wellness: Implications for Career Development and the Workplace. Career Planning \& Adult Development Journal, Vol. 33, No. 2: 66-69.

5. Bahmani, K., Semnani-Azad, Z., Adair, W. L., Sycara, K. (2018) Virtual Negotiations between Collocated Diverse Teams: The Effect of Intragroup Faultlines on Intergroup Communication, Hawaii International Conference on System Science [online] [accessed 6 May 2008] Available from Internet: < https://scholarspace.manoa.hawaii.edu/bitstream/10125/49975/1/paper0088.pdf>

6. Baltes- Patrutiu L. (2016) Experiences of digital marketers on the online communication strategy of it companies using focus-group. Bulletin of the Transilvania University of Brasov. Series VII: Social Sciences, Vol. 58, No. 9: 150-151.

7. Bianca I. (2017) The importance of online communication in the information upon safety and security at work. Bulletin of the Transilvania University of Braşov Series V: Economic Sciences, Vol. 59, No. 10: 2122; 25-26.

8. Blackbourn J.M., Fillingim J.F., Thomas C., McClelland S. Payne J. S. (2018) Two Unique Organizational Communication Systems. National Forum of Applied Educational Research Journal, Vol. 31, No. 1: 1; 3-4.

9. Bole R., Kallmyer K. (2016) Combatting the Islamic State's Digital Dominance: Revitalizing U.S. Communication Strategy. The Washington Quarterly, Vol. 39, No.: 1, 29-30.

10. Bucăța G., Rizescu A.M. (2017) The role of communication in enhancing work effectiveness of an organization, Land Forces Academy Review, Vol. 22, No. 1: 49-51.

11. Chaudhri V. (2016) Corporate Social Responsibility and the Communication Imperative: Perspectives From CSR Managers. International Journal of Business Communication, Vol. 53, No. 4: 419-442.

12. Chory R.E., Vela L.A., Avtgis T. (2015) Organizational Surveillance of Computer-Mediated Workplace Communication: Employee Privacy Concerns and Responses. Employee Responsibilities and Rights Journal, Vol. 27, No. 3: 1; 8-9;18.

13. Collyer S. (2016) Culture, Communication, and Leadership for Projects in Dynamic Environments, Project Management Journal, Vol. 47, No. 6: 111-125.

14. Dua S. (2017) Digital Communication Management: The World Is Going Digital. International Journal of Recent Research Aspects, Vol. 4, No. 3: 50-53.

15. Espinosa J. A., Nan N. Carmel E. (2015) Temporal Distance, Communication Patterns, and Task Performance in Teams, Vol. 32, No. 1: 151-155.

16. Granda T.C.V., Paladines G.F., Velásquez B. A. (2016). Digital strategic communication in Ecuador ${ }^{\text {ee }}$ public organisations. Current state and future projection. Revista Latina de Comunicación Social, Vol. 71: $211-231$.

17. Gutiérrez-Santiuste E., Gallego-Arrufat M.J., Simone A. (2016) Barriers in computer-mediated communication: Typology and evolution over time. Journal of E-Learning and Knowledge Society, Vol. 12, No. 1:1; $6-7 ; 18$.

18. Hinds J.M.; Payne S.J. (2016) Collaborative Inhibition and Semantic Recall: Improving Collaboration Through Computer-mediated Communication, Applied Cognitive Psychology, Vol. 30, No. 4: 554 - 558.

19. Hung Y.W., Higgins S. (2016) Learners' use of communication strategies in text-based and videobased synchronous computer-mediated communication environments: opportunities for language learning. Computer assisted language learning, Vol. 29, No. 5: 1-2; 5-6; 18-19.

20. Kapucu N., Haupt B. (2016) Information Communication Technology Use for Public Safety in the United States. Frontiers in communication, Vol. 8, No. 1: 1; 7.

21. Kiatsuranon K., Suwunnamek 0. (2017) Exploring Antecedents to Thai Information and Communication Technology (ICT) Organizational Performance. Asia-Pacific Social Science Review, Vol. 17, No. 2: $320 ; 323 ; 327-328$.

22. Liudwig S., Laer Van T., Ruyter, De, K., Friedman M. (2016) Untangling a Web of Lies: Exploring Automated Detection of Deception in Computer-Mediated Communication. Journal of Management Information Systems, Vol. 33, No. 2: 511-541.

23. McLean K.J. (2016) The Implementation of Bring Your Own Device (BYOD) in Primary [Elementary] Schools. Frontiers in Psychology, Vol. 7: 1739.

24. Mejias R.J., Reinig B.A., Dennis A.R., MacKenzie S.B. (2017) Observation versus Perception in the Conceptualization and Measurement of Participation Equality in Computer-Mediated Communication. Decision Sciences, Vol. 49, No. 1: 1-3. 
25. Musah Adiza A., Zulkipli G., Ahmad N.S.I. (2017) Relationship between Organizational Communication and Job Satisfaction in Temporary Work Environment: An Empirical Study of Plant Turnaround Workers. Global Business \& Management Research, Vol. 9: 73; 75-76; 81-82.

26. Pang, A., Shin, W., Lew, Z., Walther, J. (2018) Building relationships through dialogic communication: organizations, stakeholders, and computer-mediated communication. Journal of Marketing Communications, Vol. 24, No. 1: 68.

27. Park Y., A. El Sawy O., Fiss P.C. (2017) The Role of Business Intelligence and Communication Technologies in Organizational Agility: A Configurational Approach. Journal of the Association for Information Systems, Vol. 18, No. 9, Article 1.

28. Parke K., Marsden N., Connolly C. (2017) Lay Theories Regarding Computer-Mediated Communication in Remote Collaboration. Open Praxis, Vol. 9, No. 1: 17-30.

29. Peterson J., Pearce P.F., Ferguson L.A., Langford C.A. (2017) Understanding scoping reviews: Definition, purpose, and process, Journal of the American Association of Nurse Practitioners, Vol. 29, No. 1: 12-16.

30. Priante A., Ehrenhard M., van den Broek T, Need A. (2017) Identity and collective action via computer-mediated communication: a review and agenda for future research. New Media \& Society: 1; 5;18.

31. Rains, S.A., Brunner, S.R., Akers, C., Pavlich, C.A.,Goktas, S. (2017) Computer-mediated communication (CMC) and social support, Journal of Social \& Personal Relationships, Vol. 34, No. 8: 1186-1187.

32. Rashiti S.G., Ramadani V., Abazi-Alili H., Dana L. P., Ratten V. (2015) ICT, Innovation and Firm Performance: The Transition Economies Context. Thunderbird International Business Review, Vol. 59, No. 1: 9394;97;101-102.

33. Rouhshad A., Wigglesworth G., Storch N. (2016) The nature of negotiations in face-to-face versus computer-mediated communication in pair interactions. Language Teaching Research, Vol. 20, No. 4: $514 ; 533$.

34. Saunders C., Wiener M., Klett S., Sprenger S. (2017) The Impact of Mental Representations on ICTRelated Overload in the Use of Mobile Phones. Journal of Management Information Systems, Vol. 34, No. 3: 805.

35. Schumann S., Klein O., Douglas K., Hewstone M. (2017) When is computer-mediated intergroup contact most promising? Examining the effect of out-group members' anonymity on prejudice, Computers in Human Behavior, 77, 198-210.

36. Song Y., Kong S.C. (2017) Affordances and Constraints of BYOD (Bring Your Own Device) for Learning in Higher Education: Teachers' Perspectives, Internet and Higher Education, Vol. 32: 39-46.

37. Sueldo M. (2016) The impact of integrated organizational communication on organizational sustainability. Management of Organizations: Systematic Research, Vol. 75: 121; 133; 138.

38. Tarafdar M, Cooper CL, Stich J-F. (2017) The technostress trifecta - techno eustress, techno distress and design: Theoretical directions and an agenda for research. Info Systems Journal: 1-5.

39. Taylor A. M. (2016) Meta-Analysis and Computer-Mediated Communication, Psychological Reports, Vol. 118, No. 2:466-469.

40. Ziegler, N. (2015) Synchronous Computer-Mediated Communication and Interaction: A MetaAnalysis. Studies in Second Language Acquisition, Vol. 38, No. 3: 553; 585-586. 